\title{
Prevalence and drug susceptibility pattern of Salmonella isolates from apparently healthy slaughter cattle and personnel working at the Jimma municipal abattoir, south-West Ethiopia
}

\author{
Samson Takele ${ }^{1 *}\left(\mathbb{D}\right.$, Kifle Woldemichael ${ }^{2}$, Mulatu Gashaw ${ }^{1}$, Haimanot Tassew ${ }^{1}$, Moti Yohannes ${ }^{3}$ \\ and Alemseged Abdissa ${ }^{1}$
}

\begin{abstract}
Background: Salmonella species are among the most common food borne pathogens worldwide and their infection is one of the major global public health problems. During the last decade, multidrug resistant Salmonella species have greatly increased in humans and animals. So the aim of this study was to determine prevalence and antibiotic susceptibility pattern of Salmonella in apparently healthy slaughterer cattle and personnel working at the Jimma abattoir.

Method: A cross-sectional study was conducted from May to September 2016 at the Jimma abattoir. A total of 440 samples consisting of carcass swabs $(n=195)$, cattle feces $(n=195)$, and human stool $(n=50)$ were collected. Standard isolation and identification procedures were performed to identify Salmonella isolates. Antimicrobial susceptibility tests were also carried out on each isolate.

Results: The overall proportion of Salmonella positive isolates was $9.5 \%$ in all samples, of which $11.3 \%$ were from carcass swabs, $5.6 \%$ from cattle feces, and 18\% from human stool. All isolates were resistant to tasted antibiotics except Ciprofloxacin.

Conclusion: This study ascertains that Salmonella were widely distributed and significant proportions have developed resistance to routinely prescribed antibiotics. Therefore, there is needed to implement urgent intervention programs in study area.
\end{abstract}

Keywords: Salmonella, Antibiotic resistance, Cattle, Abattoir personnel

\section{Background}

Diseases caused by Salmonella represent an important public health problem worldwide. It is estimated that globally 93.8 million cases and 155,000 deaths are associated with gastroenteritis due to Salmonella species annually. Evidence indicated that $85.6 \%$ were estimated to be food borne, and infection was associated with many different food types, including beef and beef products $[1,2]$.

\footnotetext{
* Correspondence: sami1977.je@gmail.com

'Department of Laboratory Sciences, Jimma University, Jimma, Ethiopia Full list of author information is available at the end of the article
}

Pathogens are mainly disseminated through the animal trade and uncooked animal food products $[3,4]$. The process of removing the gastrointestinal tract during meat processing is regarded as one of the most important sources of contamination of carcass and organs with Salmonella at abattoirs, and also the hands of abattoir employees can be the vector to spread Salmonella through cross contamination [5-7].

In humans, in addition to concern about foodborne disease caused by Salmonella species, concern was raised about the impact of acquired antimicrobial resistance transferred among these organisms, which 
limits therapeutic options both in veterinary and public health practice $[8,9]$. Multidrug resistant (MDR) isolates were widely reported in Europe and America from travelers and adopted children [10]. Antimicrobial drug misuse, drugs prescription without susceptibility testing, self-medication, and long hospitalization were suggested as contribution to MDR in developing nations [11].

In Ethiopia, several factors including unhygienic living circumstances, tradition of raw meat consumption, and indiscriminate use of antimicrobials may substantially contribute to the occurrence of Salmonellosis. Although surveillance and monitoring systems are not in place and its epidemiology is not described, qualitative and quantitative syntheses of previous studies could shed light on the occurrence of the disease and the major serotypes that frequently cause infections. Therefore, this study was designed to determine the prevalence and antimicrobial resistance patterns of Salmonella in apparently healthy slaughtered cattle and personnel working at Jimma municipal Abattoir.

\section{Methods}

\section{Study area and period}

The study was conducted at the Jimma municipal abattoir from May to September 2016. Jimma is located $352 \mathrm{~km}$ south-west of Addis Ababa at latitude of about $7013^{\prime}-8056^{\prime} \mathrm{N}$ and longitude of about 35,052 ' - 37,037'E. Jimma town has one municipality abattoir and 200 meat retailers which directly receive slaughter service from the abattoir. At the Jimma abattoir, cattle, sheep, and goats are slaughtered. Animals for slaughter are derived from different areas of the Jimma region. Daily about 30-50 cattle, 10-25 sheep, and 5-10 goat are slaughtered in this facility (Fig. 1).

At the Jimma municipal abattoir there are two Veterinary professionals and 48 trained workers assigned by the government to undertake regular slaughtering activities. Veterinarians perform anti-mortem and post-mortem inspection, and the reaming activities are carried out by trained workers.

There was no clear division of the slaughtering process into stunning, bleeding, skinning, evisceration, chilling, cutting, or frozen delivery in the Jimma municipality abattoir. Bleeding and evisceration was conducted on a horizontal position on the floor by incising the hide at the bottom of the abdomen without flying the skin. Workers hoisted the carcass manually using a chained pulley system after flying the skin and evisceration on the floor. There were no knife and axe sharpening machines. There were no means of sterilizing equipment. Carcasses were manually quartered using axes.

\section{Study design}

A cross sectional study was conducted to find out the prevalence and antibiotic susceptibility pattern of Salmonella isolated from slaughter cattle and personnel working at the Jimma municipality abattoir.

\section{Study population}

Apparently healthy cattle ready for slaughter and abattoir workers in the Jimma municipal abattoir who were engaged in slaughtering were selected randomly. Animals and abattoir personnel with clinical symptoms of salmonellosis, and also those on antibiotic treatment for at last 2 weeks prior to the study, were the exclusion criteria.

\section{Sample collection, isolation and identification procedure}

Study samples were selected using a simple random sampling technique, and 195 slaughter cattle were sampled. Sample collection, isolation, and identification were made based on the recommendations of the International Organization for Standardization (ISO), 6579:2002 [8].

One hundred and nightly five (195) carcass swabs were collected. Each carcass was sampled on four regions, i.e., from neck, brisket, flank, and rump region. The area sampled in each region was $100 \mathrm{~cm}^{2}$, resulting in a total area of $400 \mathrm{~cm}^{2}$, using different pre-moistened commercial beef carcass sampling poly wipe kits, and the swabs were transferred to a sterile plastic cup containing $10 \mathrm{ml}$ of buffered peptone water. In addition, one (1) gram of feces from the rectum of the cattle and one (1) gram of stool sample from abattoir personnel was collected and transferred into to $9 \mathrm{ml}$ of buffered peptone water separately.

Homogenized carcass and fecal sample from the cattle and personnel were incubated at $37^{\circ} \mathrm{C}$. Then, $1 \mathrm{ml}$ and $0.1 \mathrm{ml}$ aliquot of the enrichment broths was transferred aseptically into $10 \mathrm{ml}$ of Selenite Cystine and $10 \mathrm{ml}$ of Rappaport-Vassiliadis with soya broth and incubated for $24 \mathrm{~h}$ at $37^{\circ} \mathrm{C}$ and $42{ }^{\circ} \mathrm{C}$, respectively. Following incubation, a loop full of each culture was streaked onto Brilliant Green Agar and Xylose Lysine Deoxycholate agar plates and incubated at $37{ }^{\circ} \mathrm{C}$ for 24 to $48 \mathrm{~h}$. The plates (BGA and XLD) were examined for the presence of characteristics associated with Salmonella colonies. A single positive colony showing red color with a black center on XLD and red color on BGA agars were subjected for biochemical tests for confirmation.

\section{Biochemical tests}

Salmonella isolates were identified using triple sugar iron agar, lysine iron agar, urea broth, indole test, and citrate utilization tests. These were incubated for 24 to $48 \mathrm{~h}$ at $37^{\circ} \mathrm{C}$. Colonies producing an alkaline slant with 
acid bottom and hydrogen sulfide production on TSI, positive for lysine, negative for urea hydrolysis, negative for indole test, and positive for citrate utilization were considered as Salmonella. Finally, susceptibility to antimicrobial was performed for all isolates.

\section{Antimicrobial susceptibility test}

All isolates were tested by Kirby-Bauer disk diffusion method using guidelines established by the Clinical and Laboratory Standards Institute (CLSI) [12]. In brief, by taking pure isolated colonies, bacterial suspension in test tubes was adjusted and compared to $0.5 \mathrm{McF}$ arland turbidity standards. The diluted bacterial suspension was then transferred to a Mueller-Hinton agar plate using a sterile cotton swab and seeded uniformly by rubbing the swab against the entire agar surface and left on the bench to absorb or dry. Subsequently the selected antibiotics were placed 15-20 mm apart from each other using sterile forceps and then incubated at $37{ }^{\circ} \mathrm{C}$ for 16 to $18 \mathrm{~h}$. A total of 10 selected antibiotics disks (Oxide, UK) were included: Ciprofloxacin (CIP) $5 \mu \mathrm{g}$, Chloramphinicol (C) $30 \mu \mathrm{g}$, Kanamycin (K) $10 \mu \mathrm{g}$, Ampicillin (AMP) $10 \mu \mathrm{g}$, Gentamicin (GM), Tetracycline (TE) $30 \mu \mathrm{g}$, Sulfamethoxazole Trimethoprim (SXT) 23.75/1.25 $\mu$, Streptomycin (S) $10 \mu$, Amikacin (AK) $30 \mu \mathrm{g}$ and Cephalothin (CF) $30 \mu \mathrm{g}$. Finally, the zone of inhibition was measured and interprets as susceptible, intermediate, or resistant categories assigned on the basis of the critical points recommended by the CLSI.

\section{Data quality assurance and analysis}

All the instruments used for sample processing were checked prior to the study. Proper functioning has been checked using quality control strains of Salmonella typhimurium (ATCC 14028) and E.coli (ATCC 25922). Data consistency and completeness were made all the way during data collection, data entry and analysis. Data were edited, and checked for its completeness and entered into Epi Data 3.1 then exported to Statistical Packages for Social Sciences (SPSS) version 20 for analysis.

\section{Results}

\section{Socio-demographic data of Jimma municipality abattoir} personnel

In the current study at the Jimma municipality abattoir; male personnel accounted for 44 (88\%), Thirteen (26\%) of the respondents completed primary school and $26(52 \%)$ completed high school. Thirty one (62\%) respondents were in age range of 35 to 49 years. Among the participants $23(46 \%)$ had 4-8 years work experience whereas the remaining 13(26\%) worked for 8 years and above. The majority the respondents $42(84 \%)$, were assigned as carcass processors depicted in Table 1.
Table 1 Socio-demographic data of Jimma municipality abattoir personnel from May to September 2016

\begin{tabular}{|c|c|c|c|}
\hline \multirow[t]{2}{*}{ Variable } & \multicolumn{2}{|c|}{ Isolation of Salmonella } & \multirow{2}{*}{$\begin{array}{l}\text { Total } \\
(\%)\end{array}$} \\
\hline & Negative (\%) & Positive (\%) & \\
\hline \multicolumn{4}{|l|}{ Sex } \\
\hline Male & $36(81.8)$ & $8(18.2)$ & $44(88)$ \\
\hline Female & $5(83.3)$ & $1(16.7)$ & $6(12)$ \\
\hline \multicolumn{4}{|l|}{ Age } \\
\hline $18-34$ & 15(93.8) & $1(6.25)$ & $16(32)$ \\
\hline $35-49$ & 25(80.6) & $6(19.4)$ & $31(62)$ \\
\hline$>50$ & $1(33.3)$ & $2(66.7)$ & $3(6)$ \\
\hline \multicolumn{4}{|l|}{ Marital status } \\
\hline Married & $28(80)$ & $7(20)$ & $35(70)$ \\
\hline Single & 13(86.7) & $2(13.3)$ & (30) \\
\hline \multicolumn{4}{|l|}{ Educational states } \\
\hline $1-4$ & $9(69)$ & $4(30.8)$ & $13(26)$ \\
\hline $5-8$ & $22(84.6)$ & $4(15.4)$ & $26(52)$ \\
\hline $9-12$ & $8(88.9)$ & $1(11.1)$ & $9(18)$ \\
\hline > Diploma & $2(100)$ & $0(0)$ & $2(4)$ \\
\hline \multicolumn{4}{|l|}{ Responsibility } \\
\hline carcass processor & $34(81)$ & $8(19)$ & $42(84)$ \\
\hline meat inspector & $2(100)$ & $0(0)$ & $2(4)$ \\
\hline Abattoir cleaner & $5(83.3)$ & $1(16.7)$ & $6(12)$ \\
\hline \multicolumn{4}{|l|}{ Service year } \\
\hline below1year & $3(100)$ & $0(0)$ & $3(6)$ \\
\hline $1-3$ & $11(100)$ & $0(0)$ & $11(22)$ \\
\hline $4-8$ years & 18(78.3) & $5(21.7)$ & 23(46) \\
\hline above 8 year & $9(69.2)$ & $4(30.8)$ & $13(26)$ \\
\hline
\end{tabular}

Prevalence of Salmonella in cattle and abattoir personnel A total of 440 samples, 195 carcass swabs, 195 cattle feces, and 50 stool samples from slaughter house personnel were collected from the Jimma municipality abattoir. From 440 samples, 42(9.5\%) were positive for Salmonella. Of these, 22(11.3\%) were detected from carcass swabs, 11(5.6\%) and 9(18\%) were detected from fecal samples of animal and abattoir personnel, respectively (Table 2).

\section{Antimicrobial resistance profiles of cattle and human isolates}

Resistance to Ampicillin (54.8\%), Streptomycin (42.9\%), and Tetracycline (40.5\%) were the most common resistance profiles identified among both human and cattle isolates. Different numbers of resistance were observed to Ciprofloxacin in both human and animal isolates (Table 3).

Seventeen, (40.5\%) of both human and cattle isolates indicated resistance to two or more of the antimicrobials 


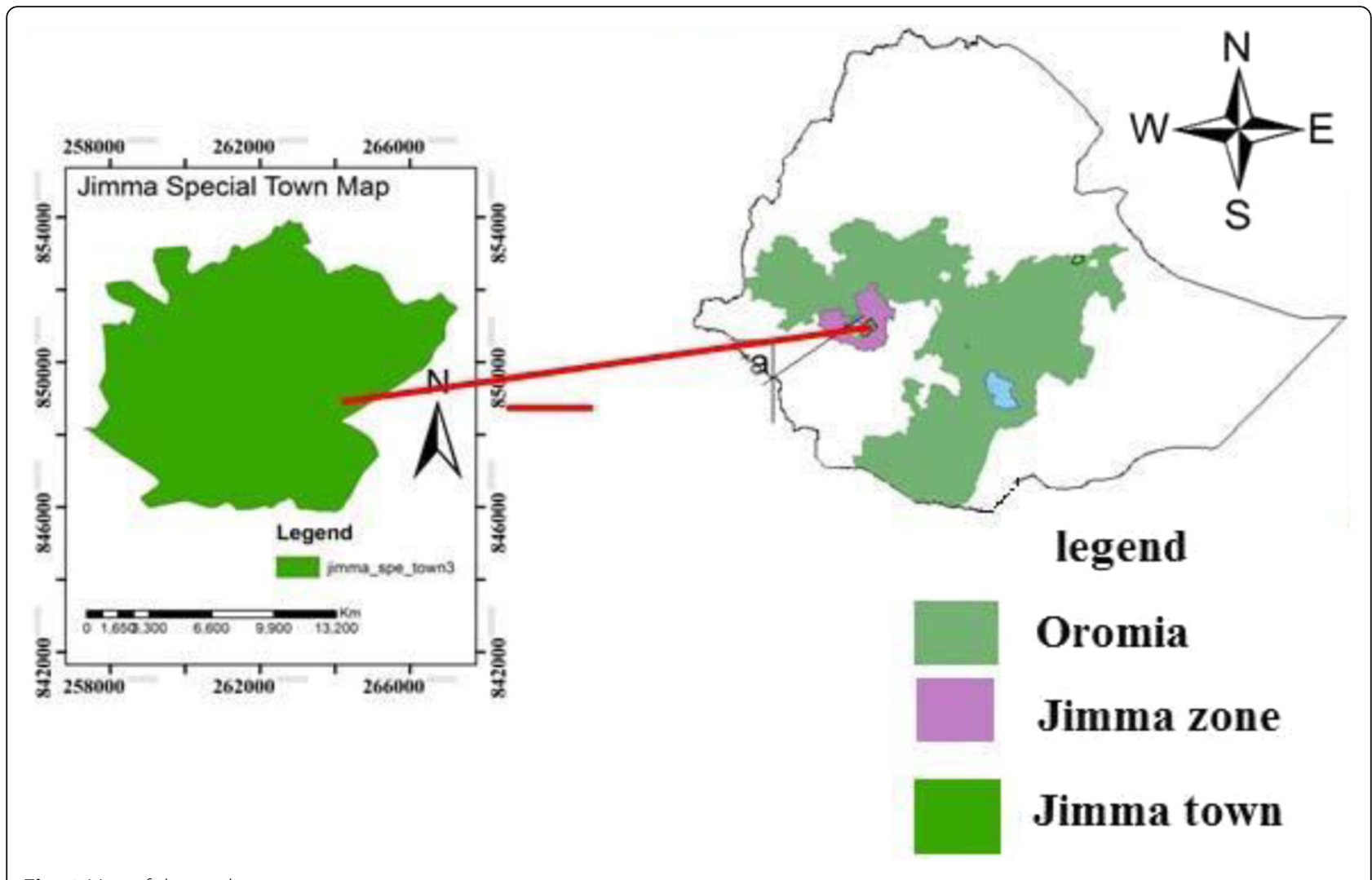

Fig. 1 Map of the study area

tested, and 10/42 (23.8\%) of human and cattle isolates were classified as intermediate level resistance (Table 4).

\section{Discussion}

In this study, Salmonella were isolated from $11.3 \%$ of samples collected from slaughter cattle carcasses. This finding reveled that there was a considerable rate of contamination in the Jimma slaughter house, which potentially poses a risk of causing food-associated illness. These findings support previous studies undertaken in the current study area, reporting $13.3 \%$ as Salmonella positive [13]. Reports from Addis Ababa indicated isolation of Salmonella from abdominal 9.8\% and from diaphragmatic muscles $11.9 \%$ [14]. The prevalence reported in the current study is higher than other reports such as $0.0 \%$ from Egypt [15], in Namibia 0.50\% [16],

Table 2 Prevalence of Salmonella in cattle and abattoir personnel in Jimma municipal abattoir from May to September 2016

\begin{tabular}{|c|c|c|c|}
\hline \multirow[t]{2}{*}{ Type of sample } & \multicolumn{2}{|l|}{ Salmonella } & \multirow{2}{*}{$\begin{array}{l}\text { Sample } \\
\text { tested }\end{array}$} \\
\hline & Positive (\%) & Negative (\%) & \\
\hline Carcass swabs & $22(11.3)$ & 173(88.7) & 195 \\
\hline Cattle Fecal & $11(5.6)$ & 184(94.4) & 195 \\
\hline Personnel Stool & $9(18)$ & $41(82)$ & 50 \\
\hline Total & $42(9.5)$ & 398(90.5) & 440 \\
\hline
\end{tabular}

4.5\% in Thailand [17], $6 \%$ in Central India [18], $8.5 \%$ in Saudi Arabia [19] 4.8\% [9], 7.6\% [20] in Baher Dar Ethiopia. This difference possibly arises from the source of animals, types of samples, and sampling technique.

The present finding showed Salmonella among individuals working in the Jimma slaughter house was 9/50 (18\%). This prevalence indicates that significant proportions of the study group were carriers of Salmonella with increased likelihood of transfer of the infection to others through contamination of food. The current finding was much higher than studies conducted elsewhere 2.4\% [19], 6.0\% [14], 3.4\% [21], 0.93\% [22] and 0.9\% [23]. The possible factors that favor the transmission and prevalence of salmonellosis may include environmental and personal sanitation, socio-economic and living standards, availability of water supply, and awareness of safe food handling and preparation among individuals.

The present study also showed that $40.3 \%$ of human and cattle isolates were resistance to two or more antimicrobial drugs. This finding is in good harmony with a study conducted in Asella town on identification and antimicrobial susceptibility profiles of Salmonella isolated from the selected dairy farms, abattoir animals and humans, which observed $50 \%$ of isolates, were resistant to two or more antimicrobials [24]. However the present results were lower than a study conducted in Addis 
Table 3 Drug susceptibility pattern of Salmonella from cattle and human isolates in Jimma municipal abattoir from May to September 2016

\begin{tabular}{|c|c|c|c|c|}
\hline \multirow{2}{*}{$\begin{array}{l}\text { Type of } \\
\text { Antimicrobials } \\
\text { Agent }\end{array}$} & \multicolumn{3}{|l|}{ Cattle isolates } & \multirow{2}{*}{$\begin{array}{l}\text { Human isolates } \\
\text { Stool sample (\%) }\end{array}$} \\
\hline & Carcass swabs (\%) & Fecal sample (\%) & Total (\%) & \\
\hline \multicolumn{5}{|c|}{ Ciprofloxacin (CIP)5 $\mu \mathrm{g}$} \\
\hline Susceptible & $22(100)$ & $11(100)$ & $33(100)$ & $9(100)$ \\
\hline Intermediate & $0(0)$ & $0(0)$ & $0(0)$ & $0(0)$ \\
\hline Resistance & $0(0)$ & $0(0)$ & $0(0)$ & $0(0)$ \\
\hline \multicolumn{5}{|c|}{ Ampicillin (AMP) $10 \mu \mathrm{g}$} \\
\hline Susceptible & $9(40.9)$ & $5(45.5)$ & $14(42.4)$ & $4(44.4)$ \\
\hline Intermediate & $0(0)$ & $0(0)$ & $0(0)$ & $1(11.1)$ \\
\hline Resistance & 13(59.1) & $6(54.5)$ & 19(57.6) & $4(44.4)$ \\
\hline \multicolumn{5}{|c|}{ Streptomycin(S)10 $\mu \mathrm{g}$} \\
\hline Susceptible & $11(50)$ & $6(54.5)$ & $17(51.5)$ & $6(66.7)$ \\
\hline Intermediate & $1(4.5)$ & $0(0)$ & $1(3.0)$ & $0(0)$ \\
\hline Resistance & $10(45.5)$ & $5(45.5)$ & $15(45.5)$ & $3(33.3)$ \\
\hline \multicolumn{5}{|c|}{ Chloramphenicol(C)3 $\mu \mathrm{g}$} \\
\hline Susceptible & 19(86.4) & $9(81.8)$ & $28(84.8)$ & $8(88.9)$ \\
\hline Intermediate & $0(0)$ & $0(0)$ & $0(0)$ & $0(0)$ \\
\hline Resistance & $3(13.6)$ & $2(18.2)$ & $5(15.2)$ & $1(11.1)$ \\
\hline \multicolumn{5}{|c|}{ Sulfamethoxazole-Trimethoprim (SXT)23.75/1.25 $\mu \mathrm{g}$} \\
\hline Susceptible & 19(86.4) & $9(81.8)$ & 28(84.8) & $8(88.9)$ \\
\hline Intermediate & $0(0)$ & $0(0)$ & $0(0)$ & $0(0)$ \\
\hline Resistance & $3(13.6)$ & $2(18.2)$ & $5(15.2)$ & $1(11.1)$ \\
\hline \multicolumn{5}{|c|}{ Tetracycline (T) $30 \mu \mathrm{g}$} \\
\hline Susceptible & $12(54.5)$ & $6(54.5)$ & $18(54.5)$ & $6(66.7)$ \\
\hline Intermediate & $0(0)$ & $1(9.1)$ & $1(3)$ & $0(0)$ \\
\hline Resistance & $10(45.5)$ & $4(36.4)$ & $14(42.4)$ & $3(33.3)$ \\
\hline \multicolumn{5}{|c|}{ Amikacin (AK) $30 \mu \mathrm{g}$} \\
\hline Susceptible & 13(59.1) & $6(54.5)$ & 19(57.6) & $6(66.7)$ \\
\hline Intermediate & $2(9.1)$ & $1(9.1)$ & $3(9.1)$ & $1(11.1)$ \\
\hline Resistance & $7(31.8)$ & $4(36.4)$ & $11(33.3)$ & $2(22.2)$ \\
\hline \multicolumn{5}{|c|}{ Gentamycin (GM) $10 \mu \mathrm{g}$} \\
\hline Susceptible & 19(86.4) & $8(72.7)$ & $27(81.8)$ & $9(100)$ \\
\hline Intermediate & $0(0)$ & $0(0)$ & $0(0)$ & $0(0)$ \\
\hline Resistance & $3(13.6)$ & $3(27.3$ & $6(18.2)$ & $0(0)$ \\
\hline \multicolumn{5}{|c|}{ Kanamycin (K)30 $\mu \mathrm{g}$} \\
\hline Susceptible & 18(81.8) & $8(72.7)$ & $26(78.8)$ & $7(77.8)$ \\
\hline Intermediate & $0(0)$ & $0(0)$ & $0(0)$ & $0(0)$ \\
\hline Resistance & $4(18.2)$ & $3(27.3)$ & $7(21.2)$ & $2(22.2)$ \\
\hline \multicolumn{5}{|c|}{ Cephalothin (CF)30 $\mu \mathrm{g}$} \\
\hline Susceptible & 18(81.8) & $9(81.8)$ & $27(81.8)$ & $5(55.6)$ \\
\hline Intermediate & $1(4.5)$ & $0(0)$ & $1(3)$ & $2(22.2)$ \\
\hline Resistance & $3(13.6)$ & $2(18.2)$ & $5(15.2)$ & $2(22.2)$ \\
\hline
\end{tabular}


Table 4 Two and above antimicrobial resistance profile of human and cattle Salmonella isolate In Jimma municipal abattoir from May to September 2016

\begin{tabular}{|c|c|c|}
\hline $\begin{array}{l}\text { Number of antimicrobials to } \\
\text { which isolate were resistance }\end{array}$ & $\begin{array}{l}\text { Antimicrobial resistant } \\
\text { pattern }\end{array}$ & Number (\%) \\
\hline Two & AMP,S (2) & $2(11.8)$ \\
\hline \multirow[t]{3}{*}{ Three } & AMP,S,AK(2) & $4(23.5)$ \\
\hline & $\mathrm{AMP}, \mathrm{S}, \mathrm{T}(1)$ & \\
\hline & $\mathrm{AMP}, \mathrm{K}, \mathrm{C}(1)$ & \\
\hline \multirow[t]{3}{*}{ Four } & AMP,S,AK,T (1) & $3(17.6)$ \\
\hline & $\mathrm{AMP}, \mathrm{S}, \mathrm{GM}, \mathrm{K}(1)$ & \\
\hline & AMP,S,T,GM (1) & \\
\hline \multirow[t]{3}{*}{ Five } & $\mathrm{AMP}, \mathrm{S}, \mathrm{AK}, \mathrm{C}, \mathrm{CF}(1)$ & $3(17.6)$ \\
\hline & AMP,S,T,GM,K (1) & \\
\hline & $\mathrm{AMP}, \mathrm{S}, \mathrm{CF}, \mathrm{T}, \mathrm{K}(1)$ & \\
\hline Seven & AMP,S,K,T,GM,SXT, CF (1) & $1(5.9)$ \\
\hline \multirow[t]{2}{*}{ Eight } & AMP,S,AK,T,K,C,SXT, CF(2) & $4(23.5)$ \\
\hline & AMP,S,AK,T,GM,CF,C,SXT(2) & \\
\hline Total & & $17(100)$ \\
\hline
\end{tabular}

Ababa where $83 \%$ of isolates were resistant to two or more antimicrobials [25]. Our study showed Ciprofloxacin (100\%), Chloramphenicol (85.7\%), Sulphamethoxazole trimetoprime (85.7\%), Gentamicin (85.7\%), Kanamicin (78.6\%), and Cephalothin (76.2\%) have good antimicrobial activity against both human and cattle Salmonella isolates. This result is comparable with previous reports from animal and human isolates in Addis Ababa [25] and Asela, Ethiopia [24]. However the present findings a contradict a study conducted at the Jimma University specialized hospital which showed all Salmonella isolates were 100\% resistant to chloramphenicol, Gentamycin and Cephalothin [26]. Another study conducted in Saudi Arabia stetted that $88.6 \%$ were resistant to Chloramphenicol [19]. The difference in Salmonella antimicrobial resistance levels in different areas of the country may be related to agent risk factors, such as virulence, pathogenicity, infectiousness, and host specificity associated with the genetic composition of Salmonella strains.

\section{Conclusion}

The carcasses associated with the Jimma municipal abattoirs were highly contaminated with Salmonella and this may pose a risk to the consumer. Some asymptomatic cattle presented for slaughter contribute to carcass contamination because of Salmonella in the intestines that has a high chance of being transferred onto the carcass and also an $18 \%$ carriage rate of Salmonella species among personnel working at the Jimma municipality abattoir. This can be a possible source of salmonellosis for the community unless carriers are treated or other preventive measures are taken. A high rate of antimicrobial resistance was observed mainly to Ampicillin, Streptomycin, and Tetracycline, and both single and multiple antimicrobial resistance patterns were observed, which is of special concern in Ethiopia due to antimicrobial resistance problems. Regulatory control of antibiotic usage in livestock and humans, and periodical health checking of workers in the abattoirs, are recommended ways to minimize contamination during carcass harvesting by following sanitation procedures and implementing stricter operation laws.

Abbreviations

BGA: Brilliant Green Agar; BPW: Buffered Peptone Water; CLSI: Clinical and Laboratory Standards Institute; MDR: Multidrug resistant; TSI: Triple Sugar Iron agar; XLD: Xylose Lysine Desoxycholate

\section{Acknowledgements}

The authors would like to express their gratitude to the One Health Center and Eastern Africa (OHCEA) for financing the research.

Funding

The research was funded by the One Health Center and Eastern Africa (OHCEA) project at the Jimma University.

\section{Availability of data and materials}

The datasets developed and/or analyzed during the current study are available from the first author or from the corresponding author upon request.

\section{Limitation of the study}

The isolated Salmonella species were not molecularly characterized due to unavailability of these resources to the laboratory facility in our country.

\section{Authors' contributions}

ST, AA, KW, MG, HT, and MY participated in conception of the research idea, methodology and review of the draft manuscript. ST carried out the laboratory work, sample collection and analysis and write up of the first draft. All authors read and approved the final manuscript.

\section{Ethics approval and consent to participate}

The study was conducted after obtaining ethical clearance from the Jimma University Health Institute Faculty of Health Sciences Ethical Review Board. A permission letter was obtained from the Jimma town Municipality Office. Written informed consent was obtained from all study participants.

\section{Consent for publication}

Not applicable

Competing interests

The authors declare that they have no competing interests.

\section{Publisher's Note}

Springer Nature remains neutral with regard to jurisdictional claims in published maps and institutional affiliations.

\section{Author details}

${ }^{1}$ Department of Laboratory Sciences, Jimma University, Jimma, Ethiopia. ${ }^{2}$ Department of Epidemiology, Jimma University, Jimma, Ethiopia. ${ }^{3}$ School of Veterinary Medicine, Jimma University, Jimma, Ethiopia.

Received: 24 July 2018 Accepted: 10 September 2018

Published online: 24 September 2018

References

1. Majowicz SE, Scallan E, Angulo FJ, O'Brien SJ, Jones TF, Fazil A, Hoekstra RM. The Global Burden of Nontyphoidal Salmonella Gastroenteritis. Clin Infect Dis. 2010;50(6):882-9. 
2. Bryce J, Boschi-Pinto C, Shibuya K, Back R. WHO estimates of the causes of death in children. Lancet. 2005;365:1147-52.

3. Morpeth SC, Ramadhani HO, Crump JA. Invasive non-Typhi Salmonella disease in Africa. Clin Infect Dis. 2010;49(4):606-11.

4. Zewdu E, Cornelius P. Antimicrobial resistance pattern of Salmonella serotypes isolated from food items and personnel in Addis Ababa, Ethiopia. Trop Anim Health Prod. 2009:41(2):241-9.

5. Alemayehu D, Molla B, Muckle A. Prevalence and antimicrobial resistance pattern of Salmonella isolates from apparently healthy slaughtered cattle in Ethiopia. Trop Anim Health Prod. 2003;35(4):309-19.

6. World Health Organization (WHO). World Health Organization global strategy for food safety: safer food for better health. Geneva, Switzerland: 2002.

7. Aftab M, Rahman A, Qureshi M, Akhter S, Sadique U, Sajid A, Zaman S. Level of Salmonella in beef of slaughtered cattle at Peshawar. J Anim Plant Sci. 2012;22:24-7.

8. Dargatz DA, Fedorka-Cray PJ, Ladely CA, Kopral CA, Ferris KE, Headrick ML. Prevalence and antimicrobial susceptibility of Salmonella spp. Isolates from US cattle in feedlots in 1999 and 2000. J Appl Microbiol. 2003;95:753-61.

9. Sefinew A, Bayleyegn M. Prevalence and antimicrobial resistance profiles of Salmonella enterica serovars isolated from slaughtered cattle in Bahir Dar, Ethiopia. Trop Anim Health Prod. 2012;44:595-600.

10. Hendriksen R, Mikoleit M, Kornschober C, Rickert R, Duyne S, Kjelso C, Hasman H, Cormican M, Mevius D, Threlfall J, Angulo F, Aarestrup F. Emergence of multidrug-resistant Salmonella Concord infections in Europe and the United States in children adopted from Ethiopia, 2003-2007. Pediatr Infect Dis J. 2009:28:814-8.

11. Hohmann EL. Nontyphoidal Salmonellosis. Clin Infect Dis. 2001;32:263-9.

12. Clinicaland Laboratory Standards Institute (CLSI). Performance for antimicrobial disk susceptibility tests; approved standard Wayne, USA , Volume 32(1). 11th edition. CLSI document M02-A11. 2012. p. 1-76.

13. Anbessa D, Ketema B. The prevalence and Antibiogram of Salmonella and Shigella isolated from. Int J Pharm Biol Res. 2012;3(4):143-8.

14. Nyeleti C, Molla B, Hildebrandt G, Kleer J. The prevalence and distribution of Salmonella in slaughter cattle, slaughterhouse personnel and minced beef in Addis Ababa, Ethiopia. Bull Anim Heal Prod Africa. 2000;48:19-24

15. El-Gamal AM, EL-Bahi EF. Molecular characterization of rectal carriage of $E$ Coli $\mathrm{O} 157$ : H7 and Salmonella Spp. In feedlot animals and its effects on carcasses contamination. Alexandria J Vet Sci. 2016;48(1):42-9.

16. Renatus P, Godwin P, Percy M. Prevalence and characterization of Salmonella isolated from beef in Namibia. Eur J Nutr Food Saf. 2015;5(4):267-74.

17. Thongsay S, Sujate C, Chaiwat P, Srirat P, Patharaphorn C, Sumalee B. Salmonella prevalence in slaughtered buffaloes and cattle in Champasak Province, Lao people' s Democratic Republic. Kasetsart J (Nat Sci). 2013;570:561-70.

18. Kalambhe D, Zade N, Chaudhari S, Shinde S, Khan W, Patil A. Isolation, antibiogram and pathogenicity of Salmonella spp. Recovered from slaughtered food animals in Nagpur region of Central India. Vet World 2016;9:176-181.

19. Bahnass M, Fathy A, Alamin M. Identification of human and animal Salmonella spp. Isolates in Najran region and control of it. Int J Adv Res. 2015:3(1):1014-22.

20. Gizachew M, Mulugeta K. Salmonella spp and risk factors for the contamination of slaughtered cattle carcass from a slaughterhouse of Bahir Dar town, E thiopia. Asian Pacific J Trop Dis. 2015;5(2):130-5.

21. Getnet F, Gebre-selassie $S$, Alemayehu H, Kassa T, Kebede N. Prevalence and antimicrobial resistance of Salmonella isolated from food handlers in Addis Ababa University students ' cafeteria, Ethiopia. African J Basic Appl Sci. 2014;6(6):210-6.

22. Birhaneselassie M, Williams D. A study of Salmonella carriage among asymptomatic food-handlers in southern Ethiopia. Int J Nutr Food Sci. 2013; 2(5):243-5.

23. Tsegaye A, Haymanot T, Beyene W, Jemal B. Contamination of bacteria and associated factors among food handlers working in the student cafeterias of Jimma University Main campus, Jimma. Altern Integr Med. 2015;4(1):185.

24. Beyene T, Yibeltie H, Chebo B, Abunna F, Beyi AF, Mammo B, et al. Identification and antimicrobial susceptibility profile of Salmonella isolated from selected dairy farms, abattoir and humans at Asella town. J Vet Sci Techno. 2016;7:3.

25. Addis Z, Kebede N, Sisay Z, Alemayehu H, Yirsaw A, Kassa T. Prevalence and antimicrobial resistance of Salmonella isolated from lactating cows and in contact humans in dairy farms of Addis Ababa : a cross sectional study. BMC Infect Dis. 2011;11:222.

26. Zenebe T, Kannan S, Yilma D, Beyene G. Original article invasive bacterial pathogens and their antibiotic susceptibility patterns in Jimma specialized hospital, Ethiop. J Heal Sci. 2011;21(1):1-8.

\section{Ready to submit your research? Choose BMC and benefit from:}

- fast, convenient online submission

- thorough peer review by experienced researchers in your field

- rapid publication on acceptance

- support for research data, including large and complex data types

- gold Open Access which fosters wider collaboration and increased citations

- maximum visibility for your research: over $100 \mathrm{M}$ website views per year

At BMC, research is always in progress.

Learn more biomedcentral.com/submissions 